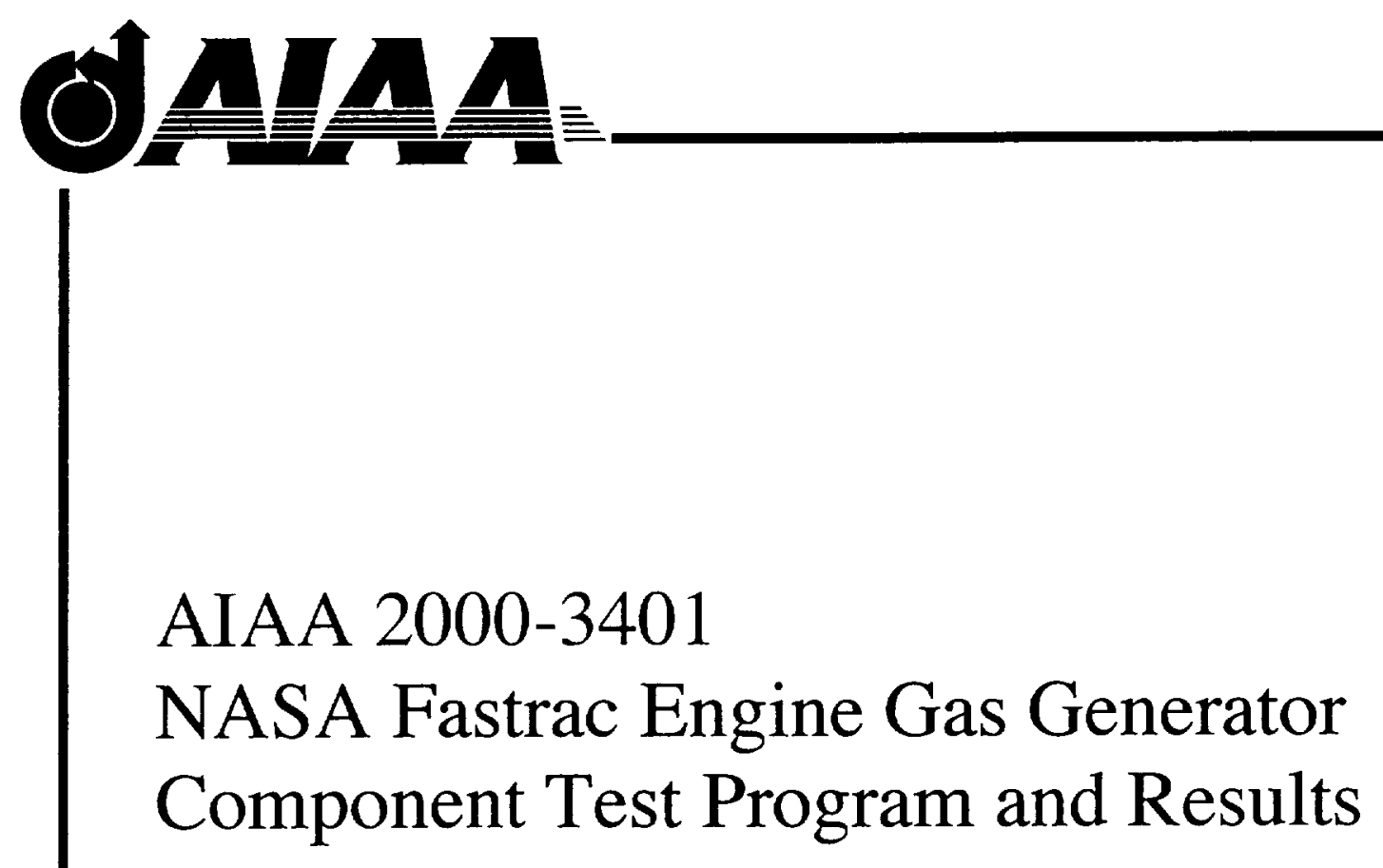

Henry J. Dennis, Jr. and Tim Sanders

NASA Marshall Space Flight Center

Huntsville, AL

\title{
$3^{\text {th }}$ AIAA/ASME/SAE/ASEE Joint Propulsion Conference$$
\text { 17-19 July } 2000
$$$$
\text { Huntsville, Alabama }
$$

For permission to copy or to republish, contact the American Institute of Aeronautics and Astronautics, 1801 Alexander Bell Drive, Suite 500, Reston, VA, 20191-4344. 


\title{
NASA FASTRAC ENGINE GAS GENERATOR COMPONFNT TFST PROGRAM AND RFSUI.TS
}

\author{
H. J. Dennis. Jr. and T. Samkers \\ NASA Marshall Space Flight Center \\ Huntsville, Alabama 35812
}

\begin{abstract}
Low cost access to space has been a long-time goal of the National Aeronautics and Space Administration (NASA). The Fastrac engine program was begun at NASA's Marshall Space Flight Center to develop a 60,000 -pound $(60 \mathrm{~K})$ thrust, liquid oxygen/hydrocarbon (LOX/RP), gas generator-cycle booster engine for a fraction of the cost of similar engines in existence. To achieve this goal, off-the-shelf components and readily available materials and processes would have to be used. This paper will present the Fastrac gas generator (GG) design and the component level hot-fire test program and results. The Fastrac $G G$ is a simple, 4 piece design that uses well-defined materials and processes for fabrication. Thirty-seven component level hot-fire tests were conducted at MSFC's component test stand \#116 (TS116) during 1997 and 1998. The GG was operated at all expected operating ranges of the Fastrac engine. Some minor design changes were required to successfully complete the test program as development issues arose during the testing. The test program data results and conclusions determined that the Fastrac GG design was well on the way to meeting the requirements of NASA's X-34 Pathfinder Program that chose the Fastrac engine as its main propulsion system.
\end{abstract}

\section{Introduction}

The Fastrac 60,000-pound thrust LOX/RP engine is being developed by MSFC for use on the X-34 test vehicle. This engine (figure 1) uses a relatively simple gas generator cycle for turbopump operation. The GG was tested as a component (figure 2) before it was used with the Fastrac turbopump or engine. This document gives a description of the GG test hardware and details for testing it as a component. Specific objectives of the component test program were to characterize the performance, stability, and hot-gas composition

Copyright $(\mathcal{C} 2000$ by the American Institute of Aeronautics and Astronautics, Inc. No copyright is asserted in the United States under Title 17, U.S. Code. The U.S. Government has a royalty-free license to exercise all rights under the copyright claimed herein for Governmental Purposes. All other rights are reserved by the copyright owner. uniformity characteristics of the $\mathrm{GG}$ and determine the injector-to-chamber wall compatibility. The GG

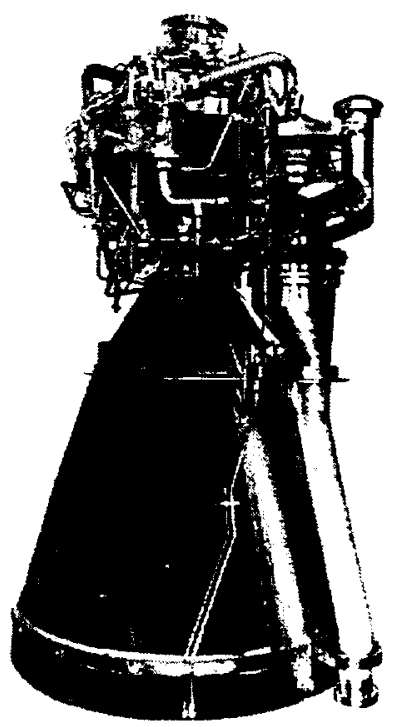

Figure 1: Fastrac Engine

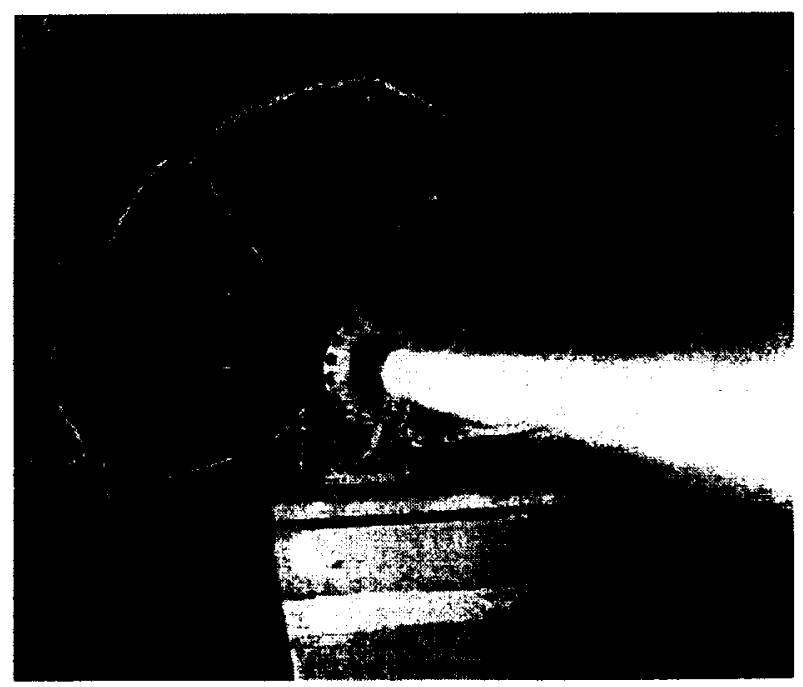

Figure 2: Fastrac GG Component Test

nominal operating conditions of 575 psia chamber pressure, $1600^{\circ} \mathrm{R}$ combustion temperature, $7.1 \mathrm{lbm} / \mathrm{sec}$ total flowrate, and 0.30 mixture ratio were established 
to conform with the design conditions planned for the Fastrac engine. Hardware performance was monitored with cavitating venturis to determine injector propellant flowrates from facility supply tank pressures, combustion chamber pressure measurements, and hot gas temperature measurements. Exhaust gas temperature and mixing uniformity was evaluated using a thermocouple rake positioned at the exit plane of the combustion chamber in front of the turbine simulator. Post-test inspections and data reviews were completed for each test.

\section{Hardware Description}

The 37 hot-fire tests were carried out with an uncooled 3.5 -inch diameter combustor that included the following components:

- Brazed impinging injector assembly

- Combustion chamber

- Instrumentation ring assembly

- Chamber Spacer(s)

- Turbine simulator(s)

\section{Brazed Injector Assembly}

Two component test injectors were fabricated. The 3.5inch diameter injector featured a drilled, impinging element OFHC (oxygen-free, high-conductivity) faceplate brazed to a single-piece, $304 \mathrm{~L}$ stainless steel propellant manifold body. The baseline injector orifice pattern consisted of 42 triplet elements ( 28 in outer row and 14 in inner row) in a circular arrangement (figure 3 ) with $28 \mathrm{film}$ coolant holes at the outer periphery. Each element was comprised of

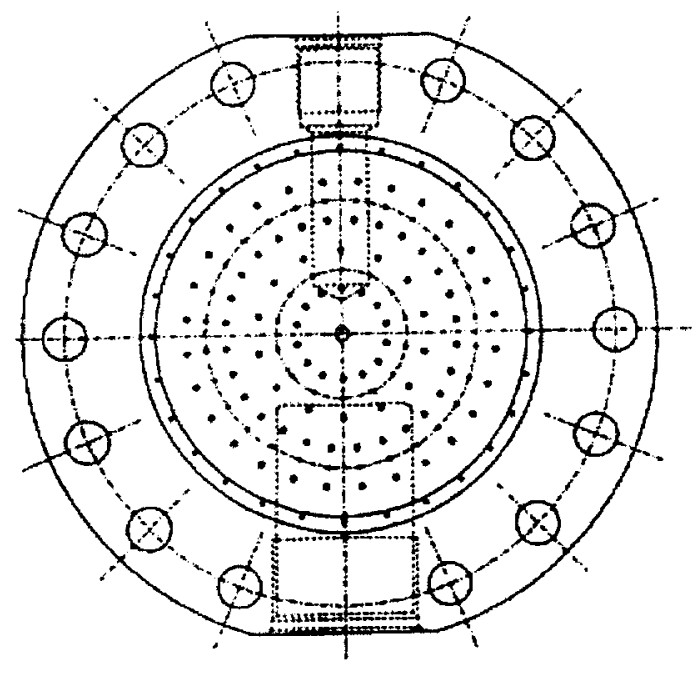

Figure 3: Injector Face one pair of self-impinging RP-I orifices enshrouding a single oxidizer showerhead orifice in a fuel-oxidizerfuel (F-O-F) triplet arrangement (figure 4). There were a total of $8+$ fuel orifices at a nominal 0.047 -inch diameter and +2 oxidizer orifices at nominal 0.033 -inch diameter. Initially there were no film coolant holes present in the injector, but development test results indicated a need for them later. The first 24 tests were

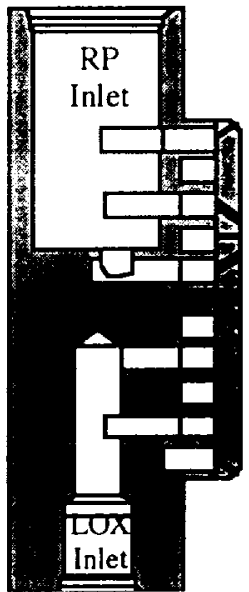

Figure 4: Injector Cross Section

conducted with a hypergolic LOX-rich ignition system. The hypergolic fluid mixture used was triethyl aluminum (TEA) and triethyl borane (TEB) or TEA/TEB, injected through a center port of the injector. Later tests were conducted with a pyrotechnic fuel-rich ignition system and the TEA/TEB port was either capped off or used to measure chamber pressure. Injector propellant pressure and temperature were measured upstream of the injector and flowrates were calculated using cavitating venturis. Some later tests added instrumentation ports to the injector to measure fuel pressure and temperature in the injector manifolding itself. Connection to the facility supply lines for LOX, RP-1, and igniter hypergolic fluids were through standard ports in the injector assembly.

\section{Combustion Chamber}

A uncooled Hastelloy-X chamber spool featured a machined turbulence ring to aid in combustion gas mixing (figure 5). The chamber inside diameter was 3.5 inches. Two component test combustion chambers were fabricated, each having a different position for the turbulence ring. One chamber placed the turbulence ring 2 inches from the injector faceplate and the other chamber placed the ring 3 inches from the faceplate. The chambers were modified later in the test series to incorporate the pyrotechnic igniter bosses. 


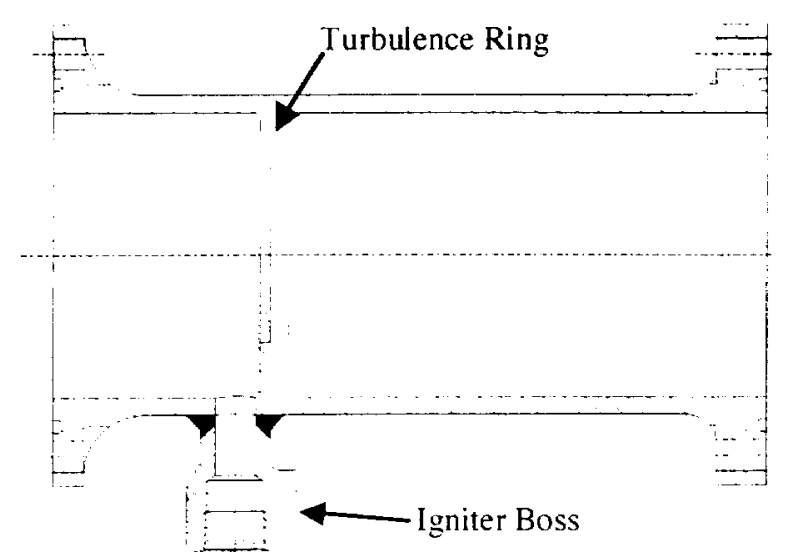

Figure 5: Combustion Chamber Cross-Section

\section{Instrumentation Ring Assembly}

An uncooled A286 instrumentation ring (figure 6) was installed just downstream of the combustion chamber.

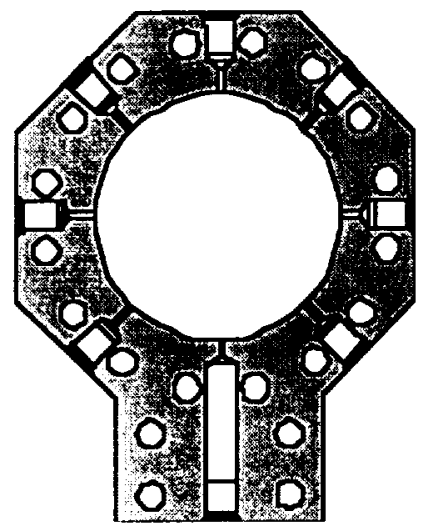

Figure 6: Instrumentation Ring

Eight ports were provided for chamber pressure and combustion gas temperature measurements. For temperature measurement, the tips of thermocouples were radially inserted into the hot gas stream at various depths to evaluate the uniformity of the combustion products.

\section{Turbine Simulators}

There were three different turbine simulators used during the 37 tests. Two of them, fabricated of A286, were simple nozzle assemblies that provided the necessary backpressure to the gas generator simulating the presence of the turbopump assembly (figure 7). One of these two simulators had three smaller "turbine" nozzles similarly sized to what was planned for the turbopump to determine the degree and effects of

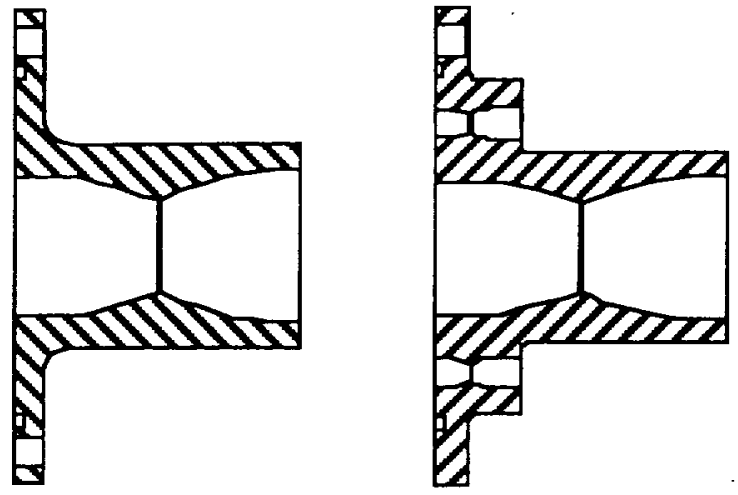

Figure 7: Turbine Simulators

combustion coking and carbon soot deposition on downstream hardware. The third turbine simulator used was an actual preliminary sandcast Inconel 718 turbopump turbine inlet manifold (TIM) unit (figure 8). The TIM had 24 square edged exhaust orifices that simulated the 24 nozzles to be used on the engine hardware. The TIM incorporated a helium spin duct port and instrumentation bosses for pressure and temperature measurements.
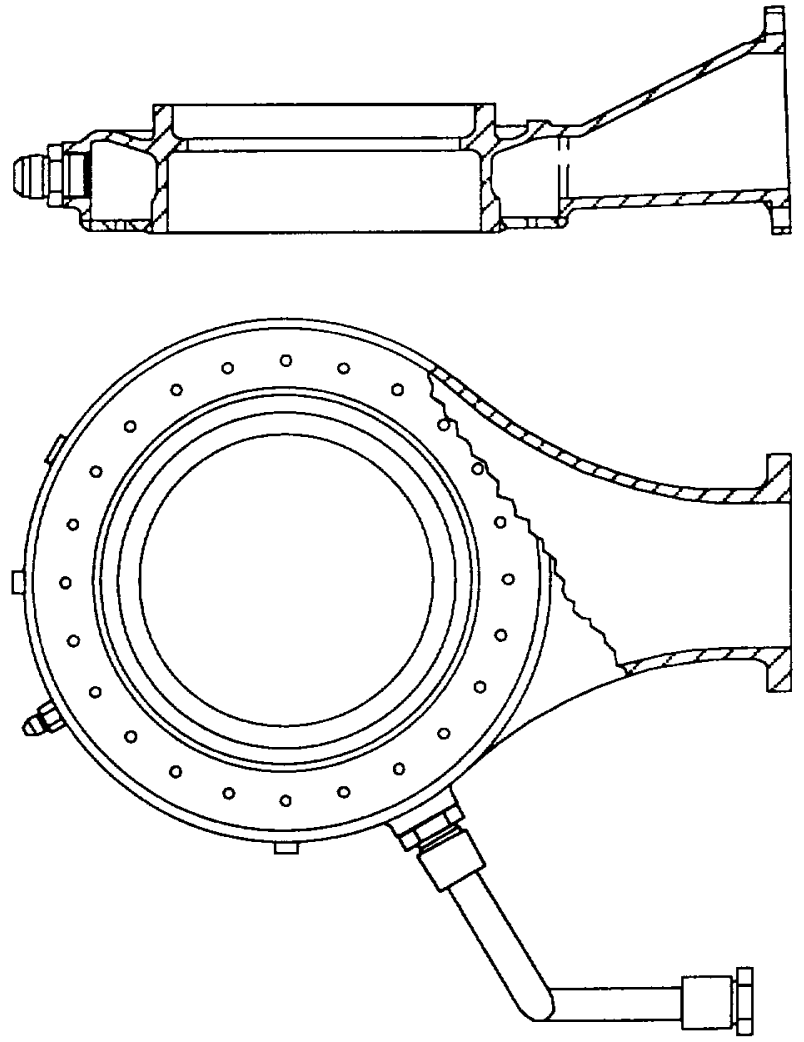

Figure 8: Turbine Inlet Manifold 


\section{Chamber Spacers}

Uncooled, 2-, 3-, and 4-inch long, 3.5 inch diameter chamber spacers were fabricated of A286 and were optional and interchangeable development test hardware pieces that allowed different length combustors to be tested. The test program results indicated the baseline chamber length of 8.5 inches was adequate for proper combustion prior to entering the turbine.

\section{Gas Generator Assembly}

A design layout of one of the test hardware assembly configurations (Figure 9) shows the injector, chamber, instrumentation ring, 2-inch chamber spacer, and a turbine simulator. The forward flange of the chamber is joined to the injector assembly and the aft flange is joined to the aft components (instrumentation ring, chamber spacer(s), and turbine simulator). Fourteen $3 / 8$-inch diameter bolts are used in the forward flange and sixteen 3/8-inch studs are used in the aft flange. A special test fixture was fabricated to mount the test article to the facility test position.

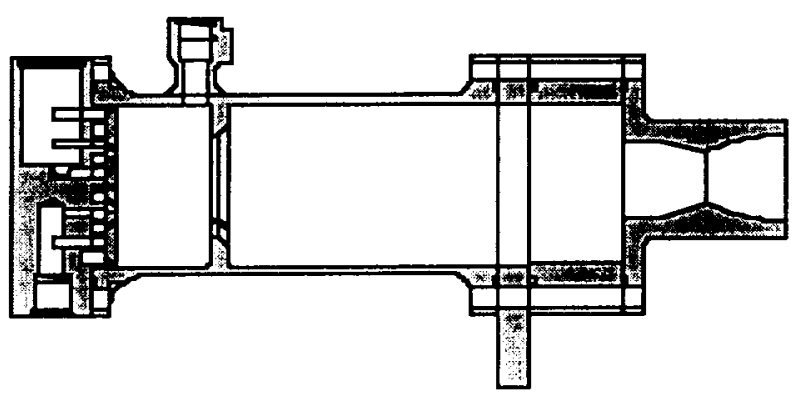

Figure 9: Test Hardware Assembly Cross-Section

\section{Test Facility Description}

Testing was performed at the turbine blade test position of component Test Stand 116 at NASA-MSFC. A simplified schematic of the test position is shown in figure 10 , with only those systems required for use in this test series shown, as follows:

$\begin{array}{lr}\text { Oxidizer: } & \text { LOX } \\ \text { LOX Pressurant \& Purge: } & \mathrm{GN}_{2} \\ \text { Fuel: } & \mathrm{RP}^{-1} \\ \text { Fuel Purge: } & \mathrm{GN}_{2} \\ \text { Igniter: } & \text { TEATEB Hypergol } \\ \text { Pressurant Purge: } & \text { or Pyrotechnic } \\ & \mathrm{GN}_{2}\end{array}$

This same facility is being used to test the Fastrac thrust chamber assembly and turbopump assembly at the component level.

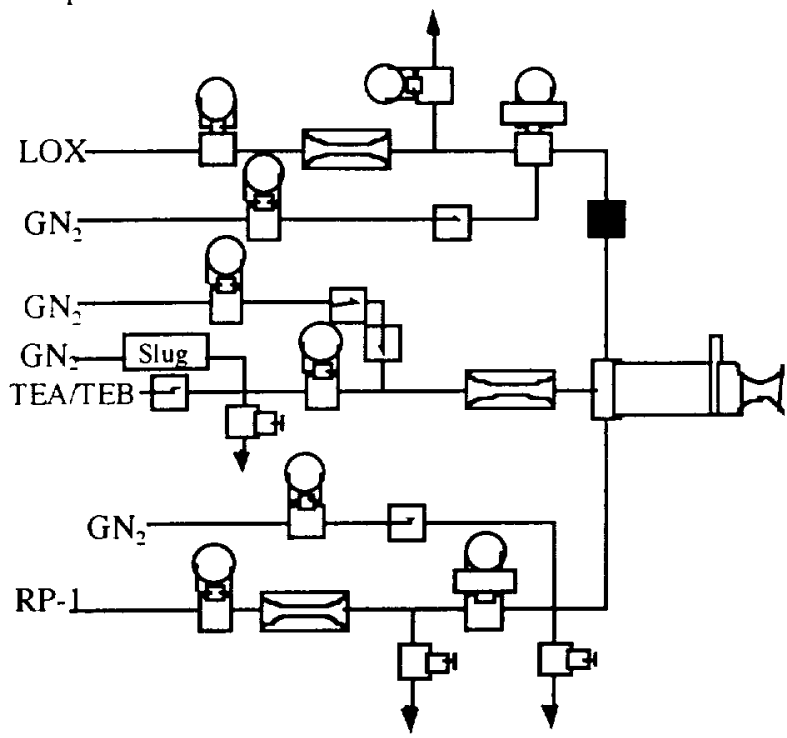

Figure 10: GG Test Position Schematic

\section{Thrust Mount}

The test hardware was bolted to a hardware support fixture which, in turn, were fastened to the test stand mount. The test hardware was angled downward approximately 2 degrees to allow residual RP-1 to drain post-test. No thrust measurements were made in this test series, but the calculated thrust generated was approximately 900 lbs. at nominal chamber pressure and injector flowrates. The combustor exhaust gases were horizontally exhausted to atmosphere.

\section{LOX System}

Oxidizer was supplied to the injector from a $5500 \mathrm{psig}$, 500 gallon LOX run tank pressurized by servocontrolled gaseous nitrogen. The pressurization servo system maintained a constant tank supply pressure during test runs. LOX flow was controlled by a cavitating venturi. LOX tank pressure was set to give the appropriate LOX flowrate through the venturi. A LOX bleed line located upstream of the main LOX valve was used to chill the LOX run line prior to initiation of each test. The main LOX valve was servo controlled but operated only in the fully open position during the test series. The purge line for the LOX system entered the LOX line just downstream of the main LOX valve. 


\section{RP-1 System}

The RP-1 propellant was fed from a 2000 psig, 3000 gallon RP-I run tank pressurized by servo-controlled gaseous nitrogen. The pressurization servo system maintained a constant tank supply pressure during test runs. Flow control for the RP-1 system was accomplished with a cavitating venturi. RP-l tank pressure was set to give the appropriate RP-I flowrate through the venturi. The main fuel valve was servo controlled but operated only in the fully open position during the test series.

\section{TEA/TEB Ignition System}

A mixture of TEA/TEB (15/85 weight percent) was used for hypergolic ignition with an oxygen lead in the test sequence. This ignition system was used for the first 24 tests in the 37 test series. TEA/TEB was supplied from a run cylinder in a 3000 psig rated system. The TEA/TEB line fed a drilled orifice in the combustor for flow control.

\section{Pyrotechnic Ignition System}

In the midst of the GG component testing, the Fastrac program made a decision to change the $G G$ ignition system to a pyrotechnic concept. It was desired to start the GG under fuel-rich conditions and eliminate the characteristic temperature spike that the engine turbine would see using the oxidizer-rich start required by a TEA/TEB hypergolic fluid. This change required the addition of a welded igniter boss to the GG combustion chamber. The first pyrotechnic igniters used were surplus squib igniters designed for the Boeing/Rocketdyne MA-5 engine. These type of igniters were used for tests 25-30. Due to the relative high cost of procuring a large number of new squib igniters from the manufacturer, an in-house MSFC design was commissioned. The MSFC design required a redesign of the igniter boss to incorporate a solid propellant plug and two NASA standard initiators (NSI) with pressure accumulators. The NSIs were proven standard hardware used on other NASA programs. A primer assembly of boron/potassium/nitrate $\left(\mathrm{BKNO}_{3}\right)$ pellets was also incorporated into the design. A crosssection of the MSFC igniter is shown in figure 11 .

\section{Test Instrumentation and Data Recording}

An instrumentation list follows. This list denotes pressure, temperature, and acceleration measurments used for the GG test article only.

1. Venturi flow measurements for LOX and RP-1 flow into injector.
2. Up to six chamber hot gas temperature measurements (T/C Rake in instrumentation ring).

3. Two chamber pressure measurements, also installed in instrumentation ring.

4. Chamber/injector axial, radial, and tangential accelerometer measurements.

5 . One high frequency chamber pressure measurement.

6. Multiple externally mounted thermocouples.

The facility had a real-time digital event recorder for review of test sequence operations related to red-line cut indications, valve command signals, and valve functions. High-speed film coverage was required on all mainstage and facility checkout tests where test hardware was at risk of being damaged or destroyed. Sequential still photography was also required from the test facility on some mainstage tests and post-test hardware evaluation records.

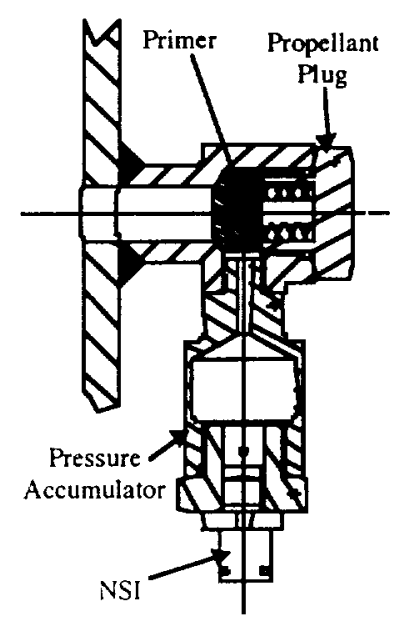

Figure 11: MSFC Pyrotechnic Igniter

\section{Test Results}

\section{Test Series 1. Nominal Operating Conditions}

The first test series consisted of three propellant blowdown tests and eight hot-fire tests. Two fuel and one LOX blowdown tests were conducted to verify the cavitating venturis were calibrated properly and determine the propellant pressure drops to be expected from the run tanks to the venturi inlets. This information was needed to properly set the run tank pressures for all subsequent tests. The first two hot-fire tests conducted were ignition tests using TEA/TEB and LOX only. No RP-1 was burned. The purpose of the ignition tests was to determine what the necessary TEA/TEB supply tank pressure level needed to be and what the subsequent GG chamber ignition pressure level would be, indicating a good ignition. 
After the blowdown and ignition tests were completed, the first mainstage test was conducted with all propellants for a 2 -second duration at mainstage. This test was a success, but the full chamber pressure of 575 psia was not achieved. Actual chamber pressure achieved was 490 psia. It was determined that the turbine nozzle simulator throat diameter was oversized. It would later be modified to allow the target chamber pressure to be reached with nominal injector flowrates. A further 4 successful hot-fire tests were conducted in this first series for $10,60,150$, and 100 seconds duration, respectively, at mainstage chamber pressure levels. All of these tests were conducted at or near the targeted 0.3 mixture ratio. The final test at 100 seconds was intended to run for 150 seconds but was terminated early due to an external fire caused by a small RP-1 leak from a facility supply line. No hardware or facility damage occurred due to the fire. The temperature rake data from these early tests indicated that the injector and turbulence ring were doing a good job of providing a relatively uniform gas temperature at the GG exit. This particular chamber had the turbulence ring that was positioned 2 inches from the injector faceplate. In all of the tests, the temperature profile varied less than 100 degrees, and in most, less than 50 degrees. A short summary of the tests in test series 1 is shown in table 1 .

\section{Test Series 2. Operational Excursion Testing}

The second test series ( 16 tests) was planned to run the $\mathrm{GG}$ at all expected operating points for the Fastrac engine. This required operating the GG at chamber pressures ranging from 465 to 670 psia and mixture ratios ranging from 0.25 to 0.35 . Early on in this test series, post-test inspections revealed that the chamber wall was locally overheating near the injector (figure 12). It appeared to be especially severe at higher fuel flowrates and low mixture ratio conditions. No injector changes had been made from the first tests series. It was first postulated that contamination found in the injector had blocked some injector elements resulting in a localized LOX rich environment in the areas that were being overheated. After the anomaly continued to occur even after the injector had been cleaned, it was decided that there was an injector flow distribution problem. Analysis later supported this. Rather than doing a complete redesign of the injector, a relatively simple modification of adding film coolant holes, was made to the existing hardware. Since the area that was overheating was consistently around the LOX inlet only, injector film coolant holes were only added to this area. The addition of these film coolant holes solved the chamber wall overheating problem during component level testing. Once engine level testing was begun, it would become necessary to add film coolant holes all around the injector. During this test series, both $G G$ chambers. each with a different turbulence ring position, were used. While there was not a great difference in the resulting hot gas uniformity, the chamber with the turbulence ring 2 inches from the faceplate appeared to provide a more uniformly mixed hot gas than the chamber with the turbulence ring 3 inches from the injector faceplate. Again, in all of the tests, the temperature profile varied less than 100 degrees at the GG exit. Figure 13 shows a representative data plot of the $G G$ exhaust gas temperature profile for a nominal condition test. It was also determined from this test series that at the range of mixture ratios and chamber pressures tested, there was no significant buildup of carbon soot on the downstream hardware. No coking or heavy buildup was encountered, but only a thin ( $\sim .005$ ") powdery layer that appeared to be self-limiting. A short summary of the tests in test series 2 is shown in table 2 .

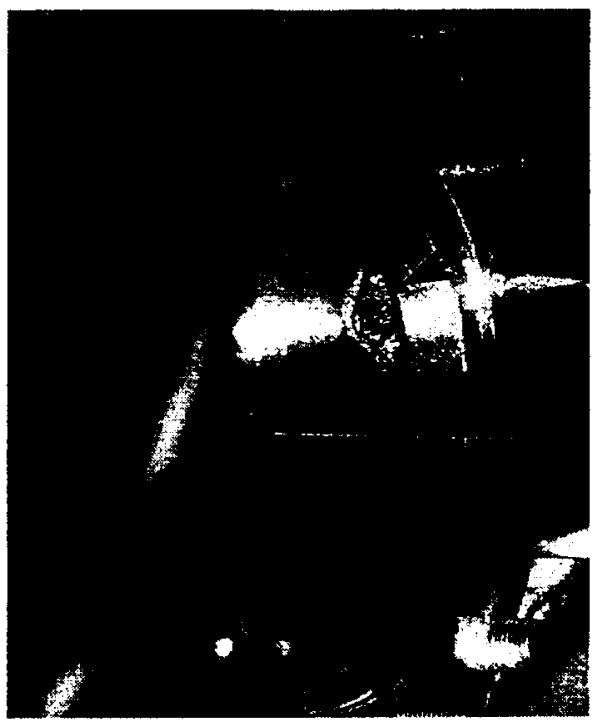

Figure 12: GG Chamber Internal Damage

\section{Test Series 3. Fuel-Rich Pyrotechnic Ignition}

The third test series (6 tests) was conducted to test the GG with a fuel-rich start using pyrotechnic igniters. Although the engine would still use TEA/TEB, LOXrich ignition for the main thrust chamber, the Fastrac engine project determined that TEA/TEB, LOX-rich ignition of the GG was not desirable for engine operation. Component testing of the $G G$ indicated there was a very transient high temperature spike as the GG combustion process transitioned through the stochiometric $\mathrm{O} / \mathrm{F}$ mixture during startup. This temperature spike was of high magnitude, but very short duration and was difficult to measure with the thermocouples used. An added benefit of changing ignition systems was to reduce by half the hazards 
involved with using hypergolics on the engine. These tests used surplus MA-5 engine igniters supplied by Boeing/Rocketdyne. In addition, this series would introduce a cast $\mathrm{TIM}$, representative of the engine design, in place of the A286 turbine simulator hardware. After four short tests to work through the ignition and valve timing and other bugs with the new start sequence, two longer duration (30 and 150 seconds) tests were conducted. Higher than nominal propellant flowrates had to be used to reach the targeted chamber pressure. This was because the cast TIM nozzle flow area was larger than the engine design point. The TIM was instrumented with several external thermocouples to evaluate the temperature profile during the longer duration tests. Unfortunately, the configuration of the test hardware and how it exhausted to atmosphere biased the data obtained from the TIM thermocouples. A short summary of the tests in test series 3 is shown in table 3 .

\section{Test Series 4. MSFC-Designed Igniter Tests}

A fourth and final test series (7 tests) was conducted to test the GG with a new MSFC-designed pyrotechnic igniter assembly (figure 11). The cost of obtaining a large supply of MA-5 igniters was prohibitive to the project, so a low-cost igniter design effort was initiated. Other than the resulting change in igniter boss configurations, the test hardware configuration was very similar to test series 3 . A helium duct was added to the TIM to allow the tests to simulate the helium environment that would be seen at the engine system level with a helium spin start for the turbopump and GG. These initial tests with the new igniters were successful, but indicated that some minor design changes would be necessary for the igniters. The last four tests in this series were run at off-nominal conditions $(\sim 45 \%$ power level and elevated $\mathrm{O} / \mathrm{F})$ to investigate whether the turbopump could be tested at this point at the component level. The results indicated that the GG performance was too unpredictable at these lower power levels. Audible low frequency buzzing was evidenced during the tests and the $C^{*}$ vs. mixture ratio characteristics of the injector were no longer predictable. Further testing at these power levels has not been pursued either at the component or engine system level. The GG internal fluctuating pressure environment and potential effects on the downstream turbine is documented in a previous study. A short summary of the tests in test series 4 is shown in table 4 .

\section{GG Design Changes Since Test Program}

Engine system level testing began in 1999 at NASA's Stennis Space Center. To date, four separate GG assemblies have been started a total of 26 times and operated for a total test time of almost 550 seconds. The engine system hardware $\mathrm{GG}$ design is essentially the same as the component test hardware, with the exception of the addition and location of instrumentation ports. Engine system level testing indicated that the GG chamber was still susceptible to overheating in localized areas near the injector. For this reason, the injector design was modified to provide film coolant holes $360^{\circ}$ around the $G G$ injector. In addition, the preload required to fasten the GG-to-TIM joint has been determined to be too great for the Hastelloy $X$ material on the GG side of the flange. The Hastelloy material yields and the fasteners and washers embed into the alloy just from the preload torque. For this reason, a recent design change has been proposed and is being incorporated to change the GG chamber material to Inconel 718. Engine test data to date has shown that the GG operates comparably to how it operated at the component level.

\section{Conclusions}

In conclusion, the Fastrac GG design appears to be a success for the application it was chosen. Component level testing has proven the design life requirement of nine starts and 1200 seconds for a single unit. The major design goal of providing a uniform hot gas profile of $1600^{\circ}+/-50^{\circ} \mathrm{R}$, at the specified flowrates and pressures, to the downstream turbine hardware has been met. The GG performance, stability, hot-gas composition uniformity, and injector-to-chamber wall compatibility have been demonstrated.

\section{Acknowledgements}

The authors would like to thank the many employees of MSFC, Summa Inc. of Huntsville, and their subcontractors who have supported this task. Their efforts have provided significant contributions in the areas of analysis, design, fabrication, and test.

\section{Reference}

1. Nesman, T., and Dennis, J., "Fastrac Gas Generator Testing", Tenth Thermal \& Fluids Analysis Workshop, UAH, September 13-17, 1999. 


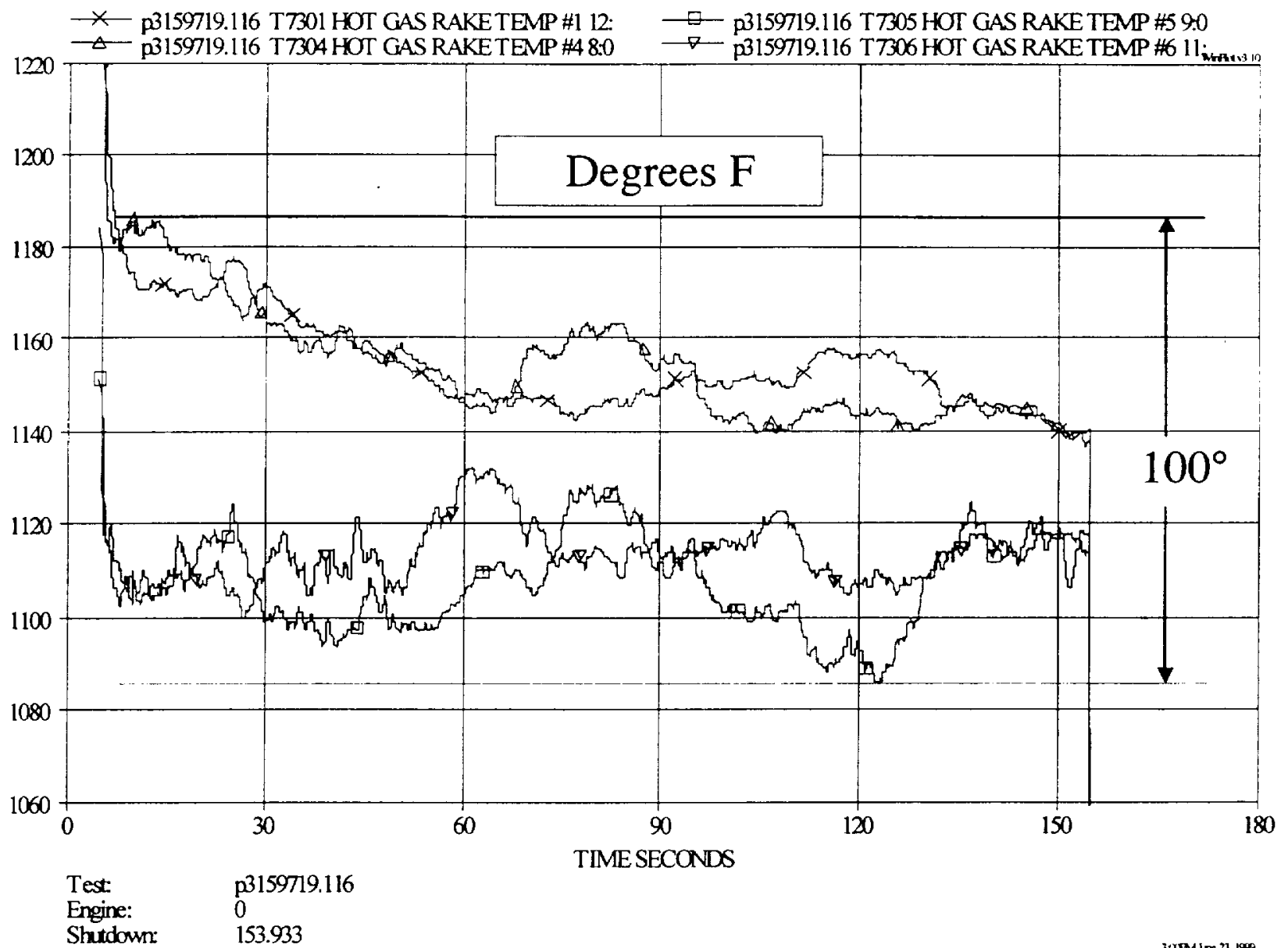

Figure 13: GG Exhaust Temperature Profile (Example) 
Table 1: Test Series 1, Nominal Operation Testing

\begin{tabular}{|c|l|c|l|}
\hline Test \# & \multicolumn{1}{|c|}{ Objective } & $\begin{array}{c}\text { Duration (sec.) } \\
\text { (mainstage/total) }\end{array}$ & \multicolumn{1}{c|}{ Results } \\
\hline fb1 & RP-1 blowdown & NA & target venturi pressure not achieved \\
\hline fb2 & RP-1 blowdown & NA & target venturi pressure achieved \\
\hline lb1 & LOX blowdown & NA & target venturi pressure achieved \\
\hline 1 & Ignition & $0 / 7.6$ & $\begin{array}{l}\text { TEA/TEB supply pressure set too low resulting in } \\
\text { intermittent combustion }\end{array}$ \\
\hline 2 & Ignition & $0 / 7.5$ & Success, Pc 150 psia \\
\hline 3 & Mainstage & $2 / 5.8$ & Success, Pc 490 psia, O/F .292 \\
\hline 4 & Mainstage & $10 / 13.8$ & Success, Pc 485 psia, O/F .291 \\
\hline 5 & Mainstage & $0 / 3.8$ & ignition Pop failed Pc sensor causing redline cut \\
\hline 6 & Mainstage & $60 / 63.8$ & Success, Pc 545 psia, O/F .3 \\
\hline 7 & Full Duration & $150 / 153.8$ & Success, Pc 545 psia, O/F .297 \\
\hline 8 & Full Duration & $100 / 103.7$ & $\begin{array}{l}\text { Partial success, Pc 550 psia, , O/F .3, external fire caused } \\
\text { early termination of test }\end{array}$ \\
\hline
\end{tabular}

Table 2: Test Series 2, Operating Excursions Testing

\begin{tabular}{|c|c|c|c|}
\hline Test \# & Objective & $\begin{array}{l}\text { Duration (sec.) } \\
\text { (mainstage/total) }\end{array}$ & Results \\
\hline 9 & $\begin{array}{l}\text { Full Duration, } \\
\text { check soot buildup }\end{array}$ & $150 / 153.9$ & $\begin{array}{l}\text { Pc } 538 \text { psia, O/F .302, chamber wall overheated near } \\
\text { injector joint }\end{array}$ \\
\hline 10 & $\mathrm{O} / \mathrm{F}$ excursion & $4 / 7.6$ & premature cut due to miscalculated redline level \\
\hline 11 & $\mathrm{O} / \mathrm{F}, \mathrm{Pc}$ excursion & $60 / 63.8$ & Pc 495 psia, O/F .258, chamber wall overheated \\
\hline 12 & $\mathrm{O} / \mathrm{F}, \mathrm{Pc}$ excursion & $20 / 23.9$ & Pc 495 psia, O/F .256, chamber ID wall erosion \\
\hline 13 & $\mathrm{O} / \mathrm{F}, \mathrm{Pc}$ excursion & $60 / 63.9$ & Pc 485 psia, O/F .245, chamber wall overheating \\
\hline 14 & $\mathrm{O} / \mathrm{F}, \mathrm{Pc}$ excursion & $60 / 63.9$ & Pc 465 psia, O/F 33 , no chamber wall overheating \\
\hline 15 & $\begin{array}{l}\mathrm{O} / \mathrm{F}, \mathrm{Pc} \text { excursion, } \\
\text { test larger RP inlet } \\
\text { line }\end{array}$ & $30 / 33.9$ & $\begin{array}{l}\text { Pc } 490 \text { psia, } O / F .25 \text { no chamber wall overheating } \\
\text { indicating improved injector flow from larger inlet line }\end{array}$ \\
\hline 16 & $\begin{array}{l}\mathrm{O} / \mathrm{F}, \mathrm{Pc} \text { excursion, } \\
\text { injector modified } \\
\text { with film coolant }\end{array}$ & $0 / 3.9$ & ut due to violation of facility redline \\
\hline 17 & $\mathrm{O} / \mathrm{F}, \mathrm{Pc}$ excursion & $60 / 63.8$ & $\begin{array}{l}\text { Success, Pc } 494 \text { psia, O/F .25, no chamber wall } \\
\text { overheating }\end{array}$ \\
\hline 18 & O/F excursion & $60 / 63.9$ & Success, Pc 565 psia, O/F 25 , rake temps. $1435-1495^{\circ} \mathrm{R}$ \\
\hline 19 & Nominal Operation & $150 / 153.9$ & Success, Pc 557 psia, O/F .30 , rake temps. $1576-1635^{\circ} \mathrm{R}$ \\
\hline 20 & $\mathrm{O} / \mathrm{F}$ excursion & $150 / 153.9$ & Success, Pc 545 psia, O/F 35 , rake temps. $1675-1739^{\circ} \mathrm{R}$ \\
\hline 21 & Pc excursion & $150 / 153.9$ & Success, $\mathrm{Pc} 481$ psia, O/F .30 , rake temps. $1515-1591^{\circ} \mathrm{R}$ \\
\hline 22 & $\mathrm{O} / \mathrm{F}, \mathrm{Pc}$ excursion & $150 / 153.9$ & Success, Pc 477 psia, O/F .36, rake temps. 1697-1762 ${ }^{\circ} \mathrm{R}$ \\
\hline 23 & Pc excursion & $60 / 63.9$ & Success, Pc 669 psia, O/F .30, rake temps. $1559-1617^{\circ} \mathrm{R}$ \\
\hline 24 & $\mathrm{O} / \mathrm{F}, \mathrm{Pc}$ excursion & $60 / 63.9$ & Success, Pc 658 psia, O/F .35, rake temps. $1676-1740^{\circ} \mathrm{R}$ \\
\hline
\end{tabular}


Table 3: Test Series 3, Pyrotechnic Ignition Series 1

\begin{tabular}{|c|l|c|l|}
\hline Test \# & \multicolumn{1}{|c|}{ Objective } & $\begin{array}{c}\text { Duration (sec.) } \\
\text { (mainstage/total) }\end{array}$ & \multicolumn{1}{c|}{ Results } \\
\hline 25 & $\begin{array}{l}\text { Pyrotechnic } \\
\text { Ignition }\end{array}$ & $0 / 1.8$ & $\begin{array}{l}\text { Ignition detect timer not long enough to allow chamber } \\
\text { pressure to rise above redline cutoff level. }\end{array}$ \\
\hline 26 & $\begin{array}{l}\text { Pyrotechnic } \\
\text { Ignition }\end{array}$ & $1 / 3.1$ & $\begin{array}{l}\text { Pc low redline cutoff due to lower than expected chamber } \\
\text { pressure with nominal propellant flowrates }\end{array}$ \\
\hline 27 & $\begin{array}{l}\text { Pyrotechnic } \\
\text { Ignition }\end{array}$ & $6 / 8.1$ & Success, Pc 545 psia, O/F .31, rake temps. 1546-1630 ${ }^{\circ} \mathrm{R}$ \\
\hline 28 & O/F excursion & $1 / 2.8$ & Accelerometer redline cutoff. \\
\hline 29 & O/F excursion & $30 / 32$ & Success, Pc 452 psia, O/F .25, rake temps. $1348-1392^{\circ} \mathrm{R}$ \\
\hline 30 & Full Duration & $150 / 152$ & Success, Pc 537 psia, O/F .31, rake temps. $1540-1588^{\circ} \mathrm{R}$ \\
\hline
\end{tabular}

Table 4: Test Series 4, Pyrotechnic Ignition Series 2

\begin{tabular}{|c|c|c|c|}
\hline Test \# & Objective & $\begin{array}{c}\text { Duration (sec.) } \\
\text { (mainstage/total) }\end{array}$ & Results \\
\hline 31 & $\begin{array}{l}\text { Demonstrate new } \\
\text { igniter }\end{array}$ & $150 / 151.6$ & Success, Pc 542 psia, O/F .31 , rake temps. $1585-1629^{\circ} \mathrm{R}$ \\
\hline 32 & $\begin{array}{l}\text { Demonstrate new } \\
\text { igniter in He-atm., } \\
\text { O/F excursion }\end{array}$ & $1.1 / 3.7$ & $\begin{array}{l}\text { Pc high cutoff. Helium flow added to } C^{*} \text { performance and } \\
\text { tripped upper } \mathrm{Pc} \text { redline just after ignition, before helium } \\
\text { was shut off. }\end{array}$ \\
\hline 33 & $\begin{array}{l}\text { Demonstrate new } \\
\text { igniter in He-atm., } \\
\text { O/F, Pc excursion }\end{array}$ & $60 / 62.6$ & Success, $\mathrm{Pc} 478$ psia, $\mathrm{O} / \mathrm{F} .34$, rake temps. $1650-1720^{\circ} \mathrm{R}$ \\
\hline 34 & $\begin{array}{l}\text { Demonstrate new } \\
\text { igniter in He-atm., } \\
\mathrm{O} / \mathrm{F}, \mathrm{Pc} \text { excursion }\end{array}$ & $30 / 32.6$ & Success, Pc 221 psia, O/F .33, rake temps. $1440-1471^{\circ} \mathrm{R}$ \\
\hline 35 & $\begin{array}{l}\text { Demonstrate new } \\
\text { igniter in He-atm., } \\
\mathrm{O} / \mathrm{F}, \mathrm{Pc} \text { excursion }\end{array}$ & $60 / 62.1$ & Success, $\mathrm{Pc} 285$ psia, $\mathrm{O} / \mathrm{F} .38$, rake temps. $1730-1786^{\circ} \mathrm{R}$ \\
\hline 36 & $\begin{array}{l}\text { Demonstrate new } \\
\text { igniter in He-atm., } \\
\mathrm{O} / \mathrm{F}, \mathrm{Pc} \text { excursion }\end{array}$ & 30.32 .6 & Success, $\mathrm{Pc} 244$ psia, $\mathrm{O} / \mathrm{F} .36$, rake temps. $1647-1690^{\circ} \mathrm{R}$ \\
\hline 37 & $\begin{array}{l}\text { Demonstrate new } \\
\text { igniter in He-atm., } \\
\mathrm{O} / \mathrm{F}, \text { Pc excursion }\end{array}$ & $30 / 32.6$ & Success, Pc 259 psia, O/F .35, rake temps. $1617-1671^{\circ} \mathrm{R}$ \\
\hline
\end{tabular}

